\title{
The Common Ground of Law and Anarchism
}

\author{
Nathan Tamblyn ${ }^{1}$ (D)
}

Published online: 30 April 2019

(C) The Author(s) 2019

\begin{abstract}
Anarchism often sets itself against the law. However, the alternative vision advanced by anarchism faces theoretical problems. Further, case studies of anarchist communities reveal practical difficulties, and resort to the very behaviour for which anarchism criticises the law. Nevertheless, the values inherent in law are strongly aligned with those championed by anarchism. Ultimately, law and anarchism need not be antithetical; they can be mutually helpful.
\end{abstract}

Keywords Anarchy · Consensus · Rule of Law

\section{Introduction}

Anarchism does not signify chaos. Rather, the word 'anarchy' comes from the ancient Greek and means 'no ruler'. This reflects the fact that anarchism tends to be grounded in notions of individual liberty and equality, free from hierarchy. Anarchist arguments can arise in a variety of contexts, such as feminism, ${ }^{1}$ or religion, ${ }^{2}$ or transgender identity, ${ }^{3}$ or animal liberation. ${ }^{4}$ Indeed, anarchist views have motivated a range of activity from radical political agendas through direct action to communities run on anarchist principles. (We shall meet some of those communities below.) In this article we are concerned with anarchist arguments against the law: ${ }^{5}$

Instead of inanely repeating the old formula, Respect the law, we say, Despise law and all its attributes! In place of the cowardly phrase, Obey the law, our cry is, Revolt against all laws!

\footnotetext{
1 Kornegger (1975).

2 Tolstoy (1936).

3 Daring et al. (2010).

4 Nocella et al. (2015).

${ }^{5}$ Kropotkin (1976, p. 31).

Nathan Tamblyn

n.tamblyn@exeter.ac.uk

1 University of Exeter Law School, Exeter EX4 4RJ, UK
} 
This article has three main sections. First, we consider the reasons in theory why some anarchists rally against the law. This provides further detail on what anarchism can stand for. However, a scrutiny of this position reveals that its alternative vision faces theoretical problems. Second, we explore some case studies of anarchist communities. These provide practical examples of what anarchy can look like, and in particular we see how these communities seek to manage disputes. This reveals that some of those theoretical problems do arise in real life, and furthermore that anarchist groups often resort to the very practices for which they criticise the law. Third, we discuss the values inherent in law as an institution and practice. Here we discover the values that anarchism and the law have in common. The end result is that the law and anarchism need not be antithetical: anarchism can use the law while staying true to its cause, and the law need not view anarchism as a threat so much as a critical friend.

\section{Criticising the Law: Force and Consensus}

Why do some anarchists despise the law? What is objectionable, they say, is that the law enables the state to repress individuals, ${ }^{6}$ and of course anarchists tend to abhor the state. ${ }^{7}$ The more particular complaint is that the state is setting rules or standards which it then imposes by force. Now, there are some anarchists who are prepared to countenance violence as a necessary evil to overcome a regime of domination. ${ }^{8}$ However, let us instead acknowledge the morally higher ground to those anarchists who object to the use of force on the consistent basis that it otherwise simply repeats a pattern of domination. ${ }^{9}$ For the peaceful anarchist, rules and standards should not be imposed by anyone, whether state or anarchist community. Rather, they should be a matter of consensus.

Such consensus is said to be truly democratic. It means that everyone affected by a decision has the opportunity to be heard, their objections are given sincere consideration, and there is a process of mutual accommodation and compromise to reach a collective decision which nobody finds strongly objectionable. ${ }^{10}$ It is a horizontal process. In contrast, for example, representative government is not democratic, because voting for a member of parliament creates a hierarchy, as parliament passes laws which apply to everyone, even though it did not consult everyone, let alone get their consent. ${ }^{11}$

\footnotetext{
6 Mazor (1978), Ferrell (1997).

7 Bakunin (1990), Casey (2012).

8 Goldman (1996), Malatesta (2015).

9 Carter (1978), Franks (2003).

${ }^{10}$ Graeber (2013), Wilson (2014).

11 Consider the levels of conceit in so far as representative government is supposedly consensual: that we consent to our member of parliament, even if we did not vote for them; that we consent to how that member votes in parliament, even if they did not consult with us; that we consent to the decision of parliament, even if the outcome is contrary to how our member voted.
} 
However, we can raise a number of theoretical objections to the importance which anarchists give to the notion of consensus.

First, not everyone sees an absence of consent as necessarily fatal to the legitimacy of an institution. For example, when it comes to democracy, some authors justify democracy on grounds other than consent: by bringing more people into the decision-making process, it is likely to be better informed, or more likely to respond to the interests of most people; ${ }^{12}$ or the best approach to coordinating our activities and facilitating continued debate when there is an irreconcilable diversity of views is a pragmatist approach which experiments, and democracy is the best system for enabling experimental institutional choices while keeping them and itself under review. $^{13}$

Similarly, when it comes to the rule of law, some authors argue that there is a moral duty to obey the law for reasons based other than in consent. Three examples might be given. (1) Law is what holds us back from a state of nature which is a perpetual war of every person against their neighbour. ${ }^{14}$ (2) Society is a joint enterprise, with rules which restrict liberty, so that those who benefit from the joint enterprise, and others' submission to the rules, should out of fairness abide by the rules themselves. ${ }^{15}$ (3) It is sometimes said that even a community of saints would require law to coordinate their activities, ${ }^{16}$ so that they do not unintentionally frustrate each other. For example, it might be better to have a rule which tells us to drive on the left, rather than have no rules of the road at all. Indeed, an anarchist might agree that such rules have moral authority for essentially the same reason, that they enable individuals to attain what they want (here, efficient driving), when the desired outcome would not be possible if everyone was acting individually. ${ }^{17}$

The point to take from all this is that the anarchist has not proven that consent or consensus is essential for the legitimacy of an institution like law (or democracy), especially when there are other theories which purport to explain such legitimacy without reverting to consent.

Second, a possible drawback with a need for consensus is the potential for change to be reduced to glacial speeds when every individual potentially has a veto over any new initiative. In this context, we should note that the law is not solely about prohibiting and punishing. There is much law which is empowering, seeking to press forward with change precisely because some sections of society have not yet made that change. Laws against discrimination immediately come to mind. How long must a black person or a transgender person suffer indignity in their community just because a minority have views which deny the equality of all people?

\footnotetext{
12 Mill (1991).

13 Knight and Johnson (2011).

14 Hobbes (1996).

15 Hart (1955), Rawls (1964).

16 George (2000, p. 1636).

17 Leipold (2015).
} 
After all, not all anarchists will be people who choose to do the right thing, as some anarchists admit. ${ }^{18}$ Some people will inevitably play the system, use their influence for personal reasons, ${ }^{19}$ or exercise their veto for political gain. It is no good saying that these people are not proper anarchists if they behave this way, because, without getting into arguments over definitions, the fact remains that these people are in the anarchist community and their behaviour needs to be addressed.

Alternatively, here is a diametrically opposed view of consensus, and yet still problematic. I just suggested that rules will not change if there is no consensus for change. Then again, why should rules persist without a consensus for them to persist? Membership of the society might change. Continuing members might change their mind. A rule passed by consensus yesterday is not binding today without that consensus continuing. Thus rules and decisions become things writ in water. Consensus rule-making can be attacked from either end: nothing changes, because of an individual veto, or nothing lasts, because of an individual veto. ${ }^{20}$

To summarise, the alternative anarchist vision of consensus seems, on the one hand, to overstate its claim when other explanations not based on consent nevertheless still exist for the legitimacy of institutions, and on the other hand, to possess the potential for significant practical difficulties likely to impede its successful application. Let us explore what happens in practice by considering some case studies of anarchist communities.

\section{Anarchist Case Studies}

(1) In 2011 there was a worldwide protest movement called Occupy, for example with makeshift camps at Wall Street in New York and outside St Paul's Cathedral in London. There were perhaps hundreds of people who camped, and thousands more who participated in the demonstrations. All this occurred during the aftermath of a global financial crisis largely caused by reckless banking practices which saw the imposition of austerity measures by governments even while the banks were bailed out with public money. The movement had a number of major themes, including protest against stark wealth inequality, undemocratic institutions which represent the interests of the privileged few, and environmental degradation. $^{21}$

\footnotetext{
18 Rothbard (1978, p. 193).

19 Henry (1985, pp. 318-320).

20 Deliberative democracy stresses the importance of reaching decisions after a process of sincere deliberation that involves mutual communication and listening, and an attempt at consensus. However, it is not necessarily opposed to majority voting to resolve conflict, and some proponents acknowledge that deliberative democracy is an ideal to strive towards even if it cannot be realised in full in practice. It is perhaps a step back from a full anarchist commitment. See Bachtiger et al. (2018).

21 The Initial Statement agreed at Occupy London in October 2011 can be read here: https://occupylond on.org.uk/about.
} 
The Occupy camps tended to be run on anarchist principles. ${ }^{22}$ Decisions were made, and censured meted out, only at the General Assembly. This moved to a system of super-majority voting, seemingly in order to be able to reach any decision at all, the unanimity of consensus proving unachievable. Censure could include denial of access to camp facilities. People who were disruptive or difficult might be shunned or systematically ignored-or more ominously: ${ }^{23}$

[T]here has to be some way to get rid of them - though usually this has to happen outside the meeting.

There are a number of criticisms we can make here.

First, if decisions are to be taken by the General Assembly, then removing members by a procedure outside that structure, for lawyers, immediately sets alarm bells ringing, not least for a lack of due process. ${ }^{24}$ Further, although the point is left unsaid, it is difficult to see how this expulsion is achieved if not by force. As Newman says, anarchists cannot rest assured that having removed law they have not created a different form of domination. ${ }^{25}$

Second, we might object that the General Assembly was itself a dominating power. After all, it was seemingly the General Assembly which gave itself the power to act as sovereign. There may well be people who refused to grant it that power, or to legitimise it by participating in its original self-constitution. As Wilson says, anarchism must resist becoming what is has so relentlessly critiqued, recreating its own forms of absolutist or dogmatic politics. ${ }^{26}$

Even those who did participate in the General Assembly are still entitled to call foul. Now, in response to that assertion, Chartier seems to suggest that an anarchist who participates in a process of rule-making or dispute resolution cannot later withdraw their consent if the end result is adverse to them. He says that the regime can enforce its decision against such a person 'without aggression'. ${ }^{27}$ This is unpersuasive. For a start, a rule or process might turn out to be misapplied or misinterpreted, and there is no reason to assume that an initially willing participant consented to that. Further, the person might simply change their mind about the merits of the rule or the process. In that regard, consent is an on-going state of affairs, and when it ends, it ends. Just because someone consented at the beginning, it does not follow that they cannot withdraw that consent, or that they are bound to all things subsequently. (This is, for example, a very important point when it comes to sexual offences.)

Third, when moving to super-majority voting, what is supposed to happen to the minority? A frequent response is that a disappointed minority might secede to

\footnotetext{
22 Prichard (Forthcoming), Graeber (2013).

23 Graeber (2013, p. 219).

24 A lawyer might hope to know at least the reason why a person is sought to be removed, and to have the facts which evidence that reason to be tested in a fair and transparent manner.

25 Newman (2012, p. 325).

26 Wilson (2014, p. 203).

27 Chartier (2013, p. 249).
} 
form their own community. However, that choice only works if the minority have somewhere else to go. What is more, there is no necessary reason why the minority should leave, rather than the majority; it takes matters no further forward simply to say that there are more of the majority without an explanation for why numbers should matter. Also, if the minority refuse to leave, once again we are confronted with the question of whether they can be forced to leave, or if they stay, whether they can be forced to conform their behaviour. In other words, super-majority voting does not eliminate the spectre of force being used against the unwilling.

Further, Halling suggests that if a community secedes from an anarchist federation, it would still have to share its natural resources. ${ }^{28}$ After all, the anarchist abhors private property, summed up in the aphorism 'Property is theft!' ${ }^{29}$ This is because ownership is seen as another hierarchical relationship. However, if the seceding community refuses to share, we are back once more to the question of whether it can be forced. Further, to the extent that the seceding community must share its resources, presumably it is also entitled to share in the natural resources of the original community, at which point it looks less and less like a secession after all.

The difficulties of sharing can be thrown into sharper relief with the following thought experiment. Along comes an invading force. What is the anarchist society to do? If they truly believe in consensus, then the anarchist could not fight the invaders without the consent of the invaders. Nor could the anarchist simply say that they are defending their freedom. Yes, the anarchist might value their freedom, but the invader might not, and if the anarchist simply says that freedom does matter after all, and that they are right, and uses force to uphold that claim, that is the same pattern of behaviour for which the anarchist criticises the law. Similarly, without risking moral hypocrisy, the anarchist community cannot say that consensus is morally essential, but only to their society, which otherwise may freely dominate others.

(2) Our second case study is taken from research on English housing cooperatives. Typically, a housing cooperative might be where residents in houses are members of an organisation which collectively owns or manages the houses. Residents might pay rent to the organisation to fund the provision or up-keep of the houses. Through its members, the organisation will formulate its own rules, and in this way residents retain a democratic control over the organisation and thus the terms on which housing is provided. ${ }^{30}$ Great store is put on individual equality, but not all cooperatives need be overtly anarchist. Nevertheless, they face similar challenges when it comes to resolving disputes.

Henry recounts an example from one cooperative where those who did not pay their rent were subjected to unannounced visits by a group of people, the purpose

\footnotetext{
${ }^{28}$ Halling (2009, p. 246).

29 Proudhon (1840, p. 2).

30 The earliest housing cooperative in England was in Rochdale in the mid nineteenth century. In 2012, Rochdale (again) saw the creation of England's first tenant and employee co-owned mutual housing society, with over 13,500 houses.
} 
being to collect the rent through the technique of 'invading members' privacy and subjecting them to intimidation'. ${ }^{31}$ Again, this sounds like coercion. After all, censure which does not coerce will not assist in upholding a rule which a party has not previously been persuaded to abide by. Indeed, there was also talk of seemingly forcible expulsions from the cooperative. Even then, Henry notes, that system was 'sufficiently stressful and insufficiently rewarding' that the cooperative switched to the use of state law as the ultimate sanction, because it was predictable, effective, rational and objective, and so not derailed by emotions and personal relations.

(3) Finchett-Maddock provides another case study on a collective in a social centre. Social centres are communally run buildings which might be occupied as a squat or rented or owned. They tend to be run on a voluntary and democratic basis, founded upon anarchist principles, and they provide a range of services or facilities, such as a library, or in this case, bicycle repair by a group of people: ${ }^{32}$

There was one scenario where an individual had stolen $£ 1700$ from the bike repair shop money, claiming that it was rightfully his as he had given his time without having been paid (although the whole ethos there is around voluntarism and mutual aid). They were in a quandary as whether to punish him through their own collective parameters, or have the state law involved - which would mean the taking of a crime reference number in order to get the money back somehow. Thus, there was the moral and the legal dilemma of (a) trying to right the situation within their means; and (b) needing the money to be reported in some way as they obviously needed it. The reason of course is that an anarchist view sees no role for prisons or the police and therefore they were arbitrary and yet necessary. The eye for an eye feeling that he encountered he portrayed as more masculine revenge, and the collective are pretty balanced, and therefore all that was done was that they named and shamed him in an article on Indymedia.

There are a number of interesting points we might note about this incident.

First is the notion that the accused had 'stolen' money. This implies property, and the claim that the money was proper to the collective, rather than the accused. Again this sits awkwardly with the anarchist creed that property is theft.

Second, the collective 'named and shamed' the accused. Admittedly it is a nonviolent response. However, there is no suggestion that the accused consented to this. No justification is offered as to why the collective were entitled unilaterally to impose their preferred outcome and tarnish his reputation, nor was there any due process to test whether the collective's assessment of the situation was correct.

Third, the collective never recovered the money. The victims went without. The only sure way of recovery was acknowledged to be recourse to the police. Perhaps this is less of a problem for $£ 1700$. However, in other circumstances, the amount

\footnotetext{
31 Henry (1985).

32 Finchett-Maddock (2010, pp. 40, 41).
} 
stolen might be greater, or the problem might not be theft but physical or sexual violence-as occurred in some Occupy camps. ${ }^{33}$ Naming and shaming will not likely prevent repeat incidents of violence.

It may be true to principle for a non-violent consensus-seeking anarchist that they suffer whatever gets done to them if they cannot convince the other party to agree to their point of view. However, a persistent submission would seem to risk denying a person's dignity, even agency. Indeed, if the correct response to any conflict is to yield, the result is the anarchist living under the rule of another's domination after all.

Instead of recourse to state law, Rothbard proposes an anarchic vision of society without a centralised system of justice. Instead, he suggests a system of private courts and enforcement agencies, which succeed or not according to market forces. ${ }^{34}$ However, this is no less repressive than state law when the person on the receiving end does not recognise the authority or rules of those private companies.

(4) A final case study might be international law, that is, those rules which govern the relationship between nation states. Some authors point to this as an actual example of an anarchist legal system, on the basis that there is no world government to enforce international law against errant states. ${ }^{35}$ In other words, these are rules which have not been imposed upon states, but have been agreed or recognised by them in their horizontal dealings with each other. The claim is that most states obey most agreed rules of international law most of the time. ${ }^{36}$ This may well be true - and it might similarly be said that most anarchists behave well in their communities, and most citizens in a society governed by the rule of law are happy with that state of affairs. However, that is the easy part; if there are only a few disagreements, the difficult question is how to resolve them. What is noticeable about international relations is how often states revert to force or the threat of force after all, whether through economic sanctions designed to coerce (for example, against Iran or Russia or North Korea), ${ }^{37}$ or outright military intervention (for example, in Afghanistan or Iraq or Libya or Syria or Crimea).

To summarise, what these case studies reveal is that the peaceful anarchist has not yet identified a system for resolving disputes successfully, nor a system which eliminates altogether the occurrence of one side unilaterally imposing its solution supported by some form of intimidation or threat of force. Perhaps the use of force is relegated to a matter of last resort, but the same could be said of the law as well. To the extent that both anarchy and the law have resort to force, anarchy cannot claim

\footnotetext{
33 Prichard (Forthcoming), Graeber (2013, p. 128).

34 Rothbard (1978).

35 Allain (2014).

36 Bull (1977, p. 137).

37 Sanctions are often seen as morally preferable to war, but they can lead just as effectively to mass suffering-without the usual levels of scrutiny attendant on any military intervention: Early and Schulze (2019).
} 
to be superior to the law in that regard. So let us take a different tack and say something now in defence of law, because anarchists might be surprised to find familiar values being instantiated here.

\section{Values Inherent in the Law-and Anarchism}

Earlier we discussed the suggestion that even a community of saints (or saintly anarchists) might require law to coordinate their activities so that they do not unintentionally frustrate each other. We can take that point further by making reference to autonomy.

Anarchism puts great store by autonomy. We could ask why autonomy matters. I have always found Mill persuasive: it allows for experiments in living, which enables the rest of us to learn from others' mistakes or discoveries; and it promotes personal fulfilment, as we exercise our own faculties to give voice to the individual configuration of life within each of us, at the same time making human society and culture so much more appealing for its colourful diversity. ${ }^{38}$ Nevertheless, Mill accepted that there were limits on autonomy, to the extent that it caused harm to others. Indeed, there is an argument here from logical consistency: if autonomy does matter, then it should be promoted but only to the point where autonomy is itself threatened.

All told, we might want the law to coordinate our diverse activities, and to demarcate the boundaries of behaviour consistent with the promotion of (anarchismendorsed) autonomy. ${ }^{39}$

According to Aquinas, to achieve such goals, the law would need to influence our behaviour, and this means that the law would need to be promulgated, and possible to comply with. ${ }^{40}$ Fuller expands on these requirements: laws must also be general, not retroactive, clear, without contradiction, reasonably constant over time, with congruence between the rule and its official application. ${ }^{41}$ Fuller calls these principles of legality the 'inner morality of law'.

Some authors object to this label on the basis that immoral law is still compatible with these procedural requirements. ${ }^{42}$ However, while of course we want our law to be substantively good, there is no point if it is not also procedurally effective. What is more, even law which is substantively bad will be constrained to a certain extent if it abides by the procedural requirements of law, that is, if it is to count as law at all, rather than, for example, the sort of random stream of demands and punishments associated with a reign of terror.

\footnotetext{
38 Mill (1859).

39 Some anarchists do accept that our substantive law does already seek to promote autonomy in some measure, for example by protecting human rights, promoting equality and curtailing violence: Newman (2012, p. 326).

40 Aquinas (ST: I-II Q 90 A 4, Q 95 A 3).

41 Fuller (1977).

42 Hart (1958), Kramer (1999).
} 
Simmonds says that laws give people an indication of how to avoid interference. ${ }^{43}$ This is because, to the extent that laws say 'do this and be punished', they necessarily also indicate when punishment will not occur. In this way, they give people spheres of freedom (from interference). Thus, he says, they embody the virtue of liberty. This may be a distinct virtue from substantive justice, but no less valuable for that.

I suggest that there are other virtues to acknowledge and add to the account.

First, the law embodies the virtue of fairness. Laws are moral preconditions to blaming someone: for example, it is not usually fair to blame or punish someone for acting in a way which was not proscribed at the time. We do evaluate systems, not only on the substantive justice of their laws, but on how fair their processes are.

Second, the law achieves its coordinating effects, not like some people train dogs, by rubbing their noses in it. Rather, it achieves coordination by directing people how to behave, and in this regard it treats people as rational agents, with a minimum of dignity.

Third, the common law has a strongly democratic tendency. It aspires to give both parties a fair hearing before an independent judge. An anarchist might object that the judge holds a hierarchical position of superiority - although that is not a problem where both parties are happy to defer to an arbiter in order to resolve their dispute. However, even with a reluctant litigant, the judge's decision is still informed and shaped by the submissions of the parties. The law can change that very day if necessary, in response to the pleas of the parties, and the law has indeed undergone such seismic shifts as individual cases mark the starting point of new doctrines. More usually, the outcome is sought to be located within a framework of consistency with previous decisions. ${ }^{44}$ The outcomes of those other cases were similarly shaped by the litigants themselves, so that, after a thousand years, we have a body of law shaped case by case by those participating in it, and continually evolving as times and circumstances require.

Thus we have virtues of liberty, fairness, dignity, and democratic participation. These virtues might only be minimally realised in any given legal system, but nevertheless they are guaranteed as the inescapable consequence of using law at all. Further, as the law improves, so these virtues can only grow. Anyone who values these virtues can have confidence in using the law, because they are inherent within the nature of law itself. They are also compatible with the anarchist cause which stands for liberty and equality, freedom from domination, and for democratic participation.

I do not deny that the substantive law could be improved upon, and that access to the courts could be fairer, and that we might want a more diverse body of participants. There is a sizeable body of literature which subjects the law to a realist or critical scrutiny: for example, that law promotes the interests of the powerful and legitimates injustice ${ }^{45}$ that it sustains racial discrimination even when purporting

\footnotetext{
43 Simmonds (2008).

44 Consistency is also a measure of fairness, in treating like cases alike, rather than giving some special treatment. On law as a dialogue between principle and consistency, see Dworkin (1998).

45 Hunt (1986).
} 
to emancipate; ${ }^{46}$ that abstract rights authorize the male experience of the world to the subjugation of women; ${ }^{47}$ or that judges decide cases by unspoken or unacknowledged premises or biases as much as by legal principles. ${ }^{48}$ Perhaps such criticisms might also be made of anarchist institutions like a general assembly. However, to the extent that these criticisms of the law can be acknowledged and addressed-even further highlighted through anarchist scrutiny-nevertheless there are lawyers committed to reform of the legal system to make it more inclusive and open. Indeed, not all critics repudiate law as a potential vehicle for radical change. And in the same way that anarchism aspires towards freedom and equality, despite the possible pitfalls that attend any human endeavour, so too law can, by its nature, make aspirational promises of liberty and fairness.

A final anarchist criticism of the law is that it is prospective; it outlaws behaviour ahead of time: ${ }^{49}$

[A] response to interpersonal conflict cannot be reasonably articulated before the conflict has arisen - only afterwards and after it has not been resolved to the mutual satisfaction of the persons involved... A retrospective response, I believe, allows and indeed encourages a creative flexibility in considering aspects of conflicts not anticipated ahead of time. It fosters tolerance of ambiguity, acknowledgment of alternative meanings (and reality systems), and respect for diversity. It bypasses a self-destructive prophecy implicit in the prospective legal principle, that conflicts over rights are inherent - universal to social life. It avoids the vicious cycle that can be generated by persistent official evidence that people are incompetent, incapable of resolving their own problems, incapable of responsibility, and therefore must be ruled, managed and appropriated by those with superior rights. It recognizes that experiences of personal conflict are essential to creative assessment and change. It means that we must restore life and the settlement of disputes to a direct face to face and collective process

This seems to reject the virtues discussed above: on this vision, people are censured after the event, without knowing in advance that their behaviour is objectionable, and without being able to plan to avoid such censure. This does not seem fair, nor does it appear to promote liberty.

Nevertheless, the common law does also have a significant retrospective element. People get on with things, and if a dispute arises, they settle it themselves, and if not, then the matter gets put before the court, which resolves the problem based upon the nuances of the circumstances of the particular case. Over a thousand years a repository of resolutions has been built up. These provide ideas for solving current problems, and so also a prospective guide to avoiding conflict. Consistency where possible is thought desirable on the basis that it is fair to treat like cases alike, but

\footnotetext{
46 Freeman (1978).

${ }^{47}$ MacKinnon (1983).

48 Frank (1932), Kaplan (1985).

49 Tifft (1979, p. 397).
} 
with a readiness to depart from precedent when that is called for, because these circumstances are different or simply because times have changed.

Thus the common law has both a prospective element, setting out in advance in general terms how to behave to avoid censure, and also a retrospective element, considering how the general law might be applied, if at all, in the novel circumstances of this particular case. We might say that it seeks a compromise between, on the one hand, the virtues of liberty and fairness, and on the other, the need for flexibility to deliver a fitting and human response in the circumstances of individual litigants.

\section{Conclusion}

Peaceful anarchists are critical of the law because ultimately the law is prepared to impose its solutions by force, against the consent of the unwilling. Instead, such an anarchist prefers to see decisions reached by consensus. However, the supremacy given to consensus fails to acknowledge that there are bases other than consent which might legitimise an institution like law, and, perhaps more importantly, that the need for consensus can give rise to a number of theoretical problems likely to hinder agreement at all, resist progressive change, and generate further disputes with those who wish to leave. The case studies show that these problems do arise in practice, with anarchist communities moving to majority voting simply to reach any decision at all, and disputes ultimately resolved by the unilateral imposition of a solution and resort to the threat of force after all. Thus anarchism cannot escape the criticisms it makes of the law. Its alternative vision is not morally superior-which is also to say that the law is not morally inferior in this regard to anarchism.

Meanwhile, the law offers a usefulness even to anarchists as it seeks to coordinate diverse activities, and to demarcate the boundaries of behaviour consistent with the promotion of autonomy. As it does so, the nature of law as an institution and practice instantiates certain values. It defines a sphere of liberty as it prescribes which behaviour will not attract interference. It instantiates dignity, in treating people as rational agents, and fairness, by tying blame to what was proscribed in advance. Also, the common law's process of dispute resolution formally accepts the equality of both parties in a procedure which has strong democratic tendencies. These are all values which align with the anarchist cause.

In the second case study, the group of anarchists did resort to the law to resolve their disputes over the payment of rent. They discovered for themselves the usefulness of the law. In the third case study, the group of anarchists desisted from invoking the aid of the law, fearing it would compromise their principles. However, the reasons discussed above suggest that it need not have been a betrayal of their values to invoke the law to resolve the disagreement between the parties. The law might have been useful for them too.

None of this is to suggest that anarchists must accept the current law as perfect. They can continue to agitate for improvements. The rule of law itself is strengthened by continued scrutiny and reform. Anarchism and the law need not be antithetical. If anarchism acknowledges the similarity of values, then it can use the law to guide behaviour and resolve disputes as anarchism strives towards it objectives. If the law 
acknowledges the similarity of values, it can view anarchism, not as a slide towards disorder, but as a critical lens for a constructive scrutiny that helps to keep the law honest, so that the law might realise its inherent values more truthfully.

Acknowledgements Thanks for their helpful comments on earlier drafts to Alex Prichard and Stephen Skinner.

\section{Compliance with Ethical Standards}

Conflict of interest The author declare that they have no conflict of interest.

Open Access This article is distributed under the terms of the Creative Commons Attribution 4.0 International License (http://creativecommons.org/licenses/by/4.0/), which permits unrestricted use, distribution, and reproduction in any medium, provided you give appropriate credit to the original author(s) and the source, provide a link to the Creative Commons license, and indicate if changes were made.

\section{References}

Allain, Jean. 2014. Anarchy and international law. Review of Contemporary Philosophy 13: 17-47.

Aquinas, Thomas. 1947. The summa theologica. (Trans. Fathers of the English Dominican Province, Benziger Bros edn.). https://dhspriory.org/thomas/summa/.

Bachtiger, Andre, et al. 2018. The oxford handbook of deliberative democracy. Oxford: Oxford University Press.

Bakunin, Mikhail. 1990. Statism and anarchy. Cambridge: Cambridge University Press.

Bull, Hedley. 1977. The anarchical society: A study of order in world politics. London: Macmillan.

Carter, April. 1978. Anarchism and violence. In Nomos XIX: anarchism, ed. J. Roland Pennock and John W. Chapman. New York: New York University Press.

Casey, Gerard. 2012. Libertarian anarchy: Against the state. London: Bloomsbury.

Chartier, Gary. 2013. Anarchy and legal order. New York: Cambridge University Press.

Daring, C.B., et al. (eds.). 2010. Queering anarchism: Addressing and undressing power and desire. Oakland: AK Press.

Dworkin, Ronald. 1998. Law's empire. Oxford: Hart Publishing.

Early, Bryan, and Marcus Schulze. 2019. Still unjust, just in different ways: How targeted sanctions fall short of just war theory's principles. International Studies Review 21: 57-80.

Ferrell, Jeff. 1997. Against the law: Anarchist criminology. In Thinking critically about crime, ed. Brian MacLean and Dragan Milovanovic. Vancouver: The Collective Press.

Finchett-Maddock, Lucy. 2010. Finding space for resistance through legal pluralism: The hidden legality of the UK social centre movement. Journal of Legal Pluralism and Unofficial Law 61: 31-52.

Frank, Jerome. 1932. What courts do in fact. Illinois Law Review 26: 645-666.

Franks, Benjamin. 2003. Direct action ethic. Anarchist Studies 11: 16-41.

Freeman, Alan David. 1978. Legitimizing racial discrimination through anti-discrimination law. Minnesota Law Review 62: 1049-1120.

Fuller, Lon. 1977. The morality of law. New Haven: Yale University Press.

George, Robert P. 2000. Kelsen and aquinas on the natural law doctrine. Notre Dame Law Review 75: $1625-1646$.

Goldman, Emma. 1996. Red Emma speaks: An Emma Goldman reader, ed. Alix Kates Shulman. London: Humanities Press.

Graeber, David. 2013. The democracy project. London: Penguin.

Halling, Matt. 2009. A law of no gods, no masters-Developing and defending a participatory legal system. Hastings International \& Comparative Law Review 32: 237-270.

Hart, H.L.A. 1955. Are there any natural rights? Philosophical Review 64: 175-191.

Hart, H.L.A. 1958. Positivism and the separation of law and morals. Harvard Law Review 71: 593-629. 
Henry, Stuart. 1985. Community justice, capitalist society, and human agency: The dialectics of collective law in the cooperative. Law \& Society Review 19: 303-327.

Hobbes, Thomas. 1996. Leviathan. Cambridge: Cambridge University Press.

Hunt, Alan. 1986. The theory of critical legal studies. Oxford Journal of Legal Studies 6: 1-45.

Kaplan, Benjamin. 1985. Do intermediate appellate courts have a law-making function? Massachusetts Law Review 70: 10-13.

Knight, Jack, and James Johnson. 2011. The priority of democracy: Political consequences of pragmatism. Princeton: Princeton University Press.

Kornegger, Peggy. 1975. Anarchism: The feminist connection. New York: The Second Wave.

Kramer, Matthew. 1999. In defence of legal positivism. Oxford: Oxford University Press.

Kropotkin, Petr Alekseevich. 1976. The essential kropotkin, eds. E Capouya and K Tompkins. London: Macmillan.

Leipold, Bruno. 2015. Political anarchism and Raz's theory of authority. Res Publica 21: 309-329.

MacKinnon, Catharine. 1983. Feminism, marxism, method and the state: Toward feminist jurisprudence. Signs: Journal of Women Culture \& Society 8: 635-658.

Malatesta, Enrico. 2015. Life and ideas: The anarchist writings of enrico malatesta, ed. Vernon Richards. Oakland: PM Press.

Mazor, Lester. 1978. Disrespect for law. In Nomos XIX: anarchism, ed. J. Roland Pennock and John W. Chapman. New York: New York University Press.

Mill, John Stuart. 1859. On liberty. London: Parker \& Son.

Mill, John Stuart. 1991. Considerations on representative government. Buffalo: Prometheus Books.

Newman, Saul. 2012. Anarchism and law: Towards a post-anarchist ethics of disobedience. Griffith Law Review 21: 307-329.

Nocella, Anthony J., et al. (eds.). 2015. Anarchism and animal liberation. Jefferson: McFarland.

Prichard, Alex. Forthcoming. Occupy and the constitution of Anarchy. In Global constitutionalism, ed. Ruth Kinna, Alex Prichard and Thomas Swann. Cambridge: Cambridge University Press.

Proudhon, Pierre-Joseph. 1840. What is property? Paris: Brocard.

Rawls, John. 1964. Legal obligation and the duty of fair play. In Law and philosophy, ed. Sidney Hook. New York: New York University Press.

Rothbard, Murray. 1978. Society without a state. In Nomos XIX: anarchism, ed. J. Roland Pennock and John W. Chapman. New York: New York University Press.

Simmonds, Nigel. 2008. Law as a moral idea. Oxford: Oxford University Press.

Tifft, Larry. 1979. The coming redefinition of crime: An anarchist perspective. Social Problems 26: 392-402.

Tolstoy, Leo. 1936. The kingdom of god is within you. London: Oxford University Press.

Wilson, Matthew. 2014. Rules without rulers. Winchester: Zero Books.

Publisher's Note Springer Nature remains neutral with regard to jurisdictional claims in published maps and institutional affiliations. 